\title{
Upper Rim Allyl- and Arylazo-Coupled Calix[4]arenes as Highly Sensitive Chromogenic Sensors for $\mathrm{Hg}^{2+}$ Ion
}

\author{
Tsui-Lien Kao,${ }^{\dagger}$ Chiung-Chiu Wang, ${ }^{\dagger}$ Yu-Ting Pan,${ }^{\dagger,}+$ Ya-Jiun Shiao, ${ }^{\dagger}$ Jhy-Yuan Yen, ${ }^{\dagger}$ \\ Chun-Mei Shu ${ }^{\dagger}$ Gene-Hsiang Lee, ${ }^{\S}$ Shie-Ming Peng, ${ }^{\S}$ and Wen-Sheng Chung*,,,+ \\ Department of Applied Chemistry, Center for Interdisciplinary Molecular Science, National Chiao Tung \\ University, Hsinchu, Taiwan 30050, R.O.C., and Department of Chemistry, National Taiwan University, \\ Taipei, Taiwan 106, R.O.C. \\ wschung@cc.nctu.edu.tw
}

Received November 30, 2004
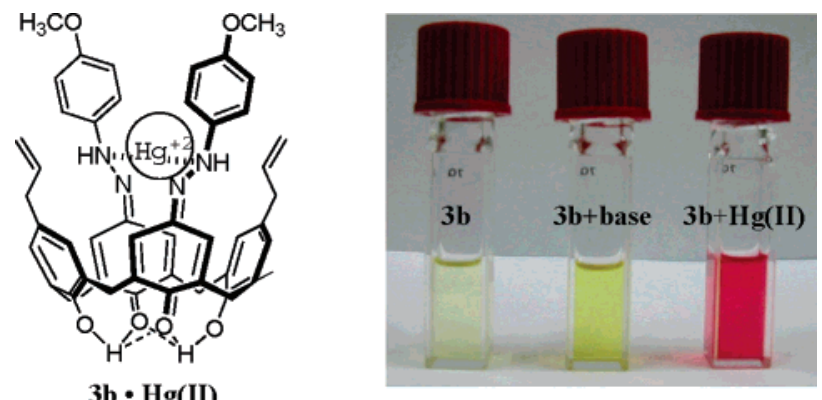

The syntheses and chromogenic properties of calix[4]arenes, carrying 5,17-bisallyl-11,23-bis( $p$-Xphenyl)azo 3a-c, 5,11,17-triallyl-23-( $p$-X-phenyl)azo 4a-c, and 5,17-bis(hydroxypropyl)-11,23-bis( $p$-X-phenyl)azo groups on the upper rims $\mathbf{5 a}, \mathbf{b}$, are described. Unexpectedly, UV/vis spectra of the very popular 4-(4-nitrophenyl)azophenol-coupled calix[4]arenes 3c and 4c did not show any shift in $\lambda_{\max }$ when 10 different metal perchlorates were added separately to the host in a methanolchloroform $(\mathrm{v} / \mathrm{v}=1 / 399)$ cosolvent. In contrast, the absorption spectra of calix[4]arenes with either 4-methoxyphenylazo $(\mathbf{3 b}-\mathbf{5 b})$ or 4-phenylazo $(\mathbf{3 a}-\mathbf{5 a})$ on the upper rim showed substantial bathochromic shifts $(\Delta \lambda=128-162 \mathrm{~nm})$ upon the addition of soft metal ions (such as $\mathrm{Hg}^{2+}, \mathrm{Cr}^{3+}$, and $\mathrm{Cu}^{2+}$ ). The 4-(4-methoxyphenyl)azophenol-coupled calix[4]arenes (the $\mathbf{3 b}-\mathbf{5 b}$ series) are found to be highly sensitive for mercury ion $\left(\mathrm{Hg}^{2+}\right)$ among the 10 different metal ions screened. Strong interactions between $\mathrm{Hg}^{2+}$ ion and the 4-(4-methoxyphenyl)azophenol(s) as well as the $p$-allyl groups are corroborated by the ${ }^{1} \mathrm{H}$ NMR studies of $\mathbf{3 a}, \mathbf{b} \cdot \mathrm{Hg}^{2+}$ complexes. Furthermore, Job's plots revealed 1:1 binding stoichiometry for all these $p$-allyl- and arylazo-coupled calix[4]arenes with transition metal ions, and Benesi-Hilderbrand plots were used for the determination of their association constants.

\section{Introduction}

The specific color change of a ligand upon metal complexation is an informative signal that can be utilized in an ion-sensing system. ${ }^{1}$ Vögtle and Takagi independently pioneered the use of 4-(4-nitrophenyl)azo-coupled crowns and azacrowns as chromoionophores, which showed large UV/vis band shifts when cations were added. ${ }^{1 a, b}$ In their work, the construction principle was as follows: mono- and diprotic chromophores were set into a crown

\footnotetext{
$\dagger$ Department of Applied Chemistry, National Chiao Tung University.

$¥$ Center for Interdisciplinary Molecular Science, National Chiao Tung University.

$\S$ National Taiwan University.
}

skeleton in such a way that the complexation of positively charged metal ions was accompanied by the dissociation of protons of the chromophore. The crown ether concept has been elegantly extended into supramolecular chemistry by the development of more rigid and selective systems such as cryptand, ${ }^{1 \mathrm{c}}$ spherand, ${ }^{\mathrm{d}}$ hemispherand, ${ }^{1 \mathrm{e}}$ and calixarene derivatives. ${ }^{1 \mathrm{f}-\mathrm{i}, 2}$

Most of the research on calix[4]arenes as chromogenic ionophores involves the modification of the lower rim with metal-chelating groups such as acids, amides, esters, ketones, or any ligand that contains lone pair electrons, and then a fluorophore or chromophore is attached on the upper rim. ${ }^{1-4}$ Shinkai and co-workers were the first to synthesize calix[4] arene with a 4-(4-nitrophenyl)- 
azophenol unit and three ether ester residues on the lower rim. They found that on cation complexation in the presence of imidazole, the complex exhibits a new absorption maximum at $600 \mathrm{~nm}$, which is a "perfect" lithium sensor. ${ }^{2 a}$ It should be noted that imidazole alone does not cause any spectral change, confirming that deprotonation and complexation are integral events in the chromogenic response. A gas sensor for colorimetric determination of trimethylamine was later devised by McCarrick et al. ${ }^{2 b}$ using a calix[4]arene bearing 4-(4nitrophenyl)azophenol residues on the lower rim. Furthermore, Reinhoudt et al. also reported that a calix[4]arene with monoalkylated 4-(4-nitrophenyl)azophenol and triamides on the lower rim is a highly selective $\mathrm{Pb}^{2+}$ sensor, in which the direction of the shift was dependent on the conformation of the calixarenes. ${ }^{4}$

Undoubtedly, 4-(4-nitrophenyl)azophenol is one of the most popular and thoroughly studied chromogenic centers in chromoionophores. ${ }^{2,4}$ However, the azo group is usually considered to be only a chromogenic center, not a metal-chelating site; therefore, lower rim modification of calix[4]arene is usually required to endow it with metal-chelating ability (vide supra). ${ }^{2-4}$ Herein, we describe the synthesis and spectroscopic evaluation of eight upper rim allyl- and arylazo-coupled calix[4]arenes $\mathbf{3 a -}$ $\mathbf{c}, 4 \mathbf{a}-\mathbf{c}$, and $\mathbf{5 a}, \mathbf{b}$, without lower rim modification. Surprisingly, those with 4-phenyl- or 4-(4-methoxyphenyl)-azophenol-coupled calix[4] arenes $(\mathbf{3 a}-\mathbf{5 a}$ and $\mathbf{3 b}$ 5b series, respectively) were found to be excellent chromogenic ionophores for transition metal ions, especially for $\mathrm{Hg}^{2+}$ ion. The $\mathrm{Hg}^{2+}$ detection by $\mathbf{3 b}-\mathbf{5 b}$ gives rise to

(1) (a) Löhr, H. G.; Vögtle, F. Acc. Chem. Res. 1985, 18, 65 and references therein. (b) Hayashita, T.; Takagi, M. In Comprehensive Supramolecular Chemistry; Atwood, J. L., Davies, J. E. D., MacNicol, D. D., Vögtle, F., Suslick, K. S., Eds.; Pergamon: Oxford, 1996; pp 635669. (c) Zazulak, W.; Chapoteau, E.; Czech, B. P.; Kumar, A. J. Org. Chem. 1992, 57, 6720. (d) Kaneda, T.; Umeda, S.; Tanigawa, H. Misumi, S.; Kai, Y.; Morii, H.; Miki, K.; Kasai, N. J. Am. Chem. Soc. 1985, 107, 4802. (e) Helgeson, R. C.; Czech, B. P.; Chapoteau, E.; Gebauer, C. R.; Kumar, A.; Cram, D. J. J. Am. Chem. Soc. 1989, 111, 6339. (f) Gutsche, C. D. Calix[4]arenes; The Royal Society of Chemistry: Cambridge, UK, 1989. (g) Diamond, D.; McKervey, M. A. Chem. Soc. Rev. 1996, 15. (h) Ikeda, A.; Shinkai, S. Chem. Rev. 1997, 97, 1713. (i) Gutsche, C. D. Calix[4]arenes Revisited; The Royal Society of Chemistry: Cambridge, UK, 1998; pp 164-165. (j) Ludwig, R. In Calixarenes 2001; Kluwer Academic: Dordrecht, The Netherlands, 2001; pp 598-611. (k) Lee, D. H.; Lee, K. H.; Hong, J.-I. Org. Lett. 2001, 3, 5 .

(2) For 4-nitrophenylazophenol-coupled calix[4] arenes as chromogenic ionophores, see: (a) Shimizu, H.; Iwamoto, K.; Fujimoto, K. Shinkai, S. Chem. Lett. 1991, 2147. (b) McCarrick, M.; Harris, S. J.; Diamond, D. J. Mater. Chem. 1994, 4, 217. (c) Gordon, J. L. M.; Böhmer, V.; Vogt, W. Tetrahedron Lett. 1995, 36, 2445. (d) Yamamoto, H.; Ueda, K.; Sandanayake, K. R. A. S.; Shinkai, S. Chem. Lett. 1995, 497. (e) Chawla, H. M.; Srinivas, K. J. Org. Chem. 1996, 61, 8464. (f) Kim, N. Y.; Chang, S.-K. J. Org. Chem. 1998, 63, 2362. (g) Ma, Q.; Ma, H.; Su, M.; Wang, Z.; Nie, L.; Liang, S. Anal. Chim. Acta 2001, 439, 73. (h) Oueslati, F.; Dumazet-Bonnamour, I.; Lamartine, R. Tetrahedron Lett. 2001, 42, 8177. (i) Halouani, H.; Dumazet-Bonnamour, I.; Lamartine, R. Tetrahedron Lett. 2002, 43, 3785. (j) Kim, J. S.; Shon, O. J.; Lee, J. K.; Lee, S. H.; Kim, J. Y.; Park, K.-M.; Lee, S.-S. J. Org. Chem. 2002 67, 1372. (k) Kim, J. Y.; Kim, G.; Kim, C. R.; Lee, S. H.; Lee, J. H.; Kim, J. S. J. Org. Chem. 2003, 68, 1933. (1) Lee, S. H.; Kim, J. Y.; Ko, J.; Lee, J. Y.; Kim, J. S. J. Org. Chem. 2004, 69, 2902.

(3) (a) Talanova, G. G.; Hwang, H.-S.; Talanov, V. S.; Bartsch, R. A. Chem. Commun. 1998, 419. (b) Talanova, G. G.; Hwang, H.-S.; Talanov, V. S.; Bartsch, R. A. Chem. Commun. 1998, 1329.

(4) (a) Cobben, P. L. H. M.; Egberink, R. J. M.; Bomer, J. G.; Bergveld, P.; Verboom, W.; Reinhoudt, D. N. J. Am. Chem. Soc. 1992 114, 10573. (b) van der Veen, N. J.; Egberink, R. J. M.; Engbersen, J. F. J.; van Veggel, F. J. C. M.; Reinhoudt, D. N. Chem. Commun. 1999 681. (c) van der Veen, N. J.; Rozniecka, E.; Woldering, L. A.; Chudy, M.; Huskens, J.; van Veggel, F. J. C. M.; Reinhoudt, D. N. Chem. Eur. J. 2001, 7, 4878. marked changes in the absorption spectra (from light yellow to bright red), which are clearly visible to the naked eye. However, for 4-(4-nitrophenyl)azophenolcoupled calix[4]arenes (the $\mathbf{3 c}-\mathbf{4 c}$ ), no transition-metal ion sensing was observed. Lower rim modification of $\mathbf{3 b}$ and $3 \mathbf{c}$ with ether-esters gave chromoionophores $6 \mathbf{b}$ and 6c, which were also used in metal ion screening.

\section{Results and Discussion}

We have followed literature procedures for the preparation of compounds $\mathbf{1},{ }^{5 a, b} \mathbf{2}^{5 b}$ and $\mathbf{3 a}-\mathbf{c}^{5 c, d}$ Besides traditional organic spectroscopic identification $\left({ }^{1} \mathrm{H}\right.$ and ${ }^{13} \mathrm{C}$ NMR, MS, and HRMS spectra) of all these calix[4]arenes, single-crystal X-ray analysis of $\mathbf{3 a}$ and $\mathbf{3 c}$ confirmed their structures to be in cone conformations (Figure 1). Calix[4] arenes $\mathbf{4 a}-\mathbf{c}$ were synthesized in 73$91 \%$ yields using a method similar to that used in the preparation of $\mathbf{3 a}-\mathbf{c}$ (Scheme 1). Hydroboration ${ }^{6}$ of the allyl groups on $\mathbf{3 a}$ and $\mathbf{3 b}$ using 4 equiv of $\mathrm{BH}_{3} \cdot \mathrm{THF}$ followed by hydrogen peroxide treatment under basic conditions gave $\mathbf{5 a}$ and $\mathbf{5 b}$ in 39 and 58\% yields, respectively. Furthermore, lower rim esterification ${ }^{7}$ of azo $\mathbf{3 b}$ and $\mathbf{3 c}$ by sodium hydride and ethyl bromoacetate in large excess (20 equiv) gave $\mathbf{6 b}$ and $\mathbf{6 c}$ in 74 and $36 \%$ yields, respectively (Scheme 2). The presence of the doublets (or broad singlets) around $\delta 4.2-4.4$ and 3.43.7 in the ${ }^{1} \mathrm{H}$ NMR spectra ${ }^{1 \mathrm{f}}$ and two methylene bridge resonances (only one for compounds $\mathbf{6 b}, \mathbf{c}$ ) at about $\delta 32$ in the ${ }^{13} \mathrm{C}$ NMR spectra ${ }^{1 f}$ for compounds $3 \mathbf{a}-\mathbf{c}, \mathbf{4 a}-\mathbf{c}$, $\mathbf{5 a}, \mathbf{b}$, and $\mathbf{6 b}, \mathbf{c}$ indicated that they are in cone conformations (see Experimental Section for details).

It is known that 4-( $p$-X)-phenylazo-1-naphthol undergoes an azo/hydrazone tautomerization in polar media, and the quinone-hydrazone form is found to be highly favored in polar solvents. Moreover, the azo/hydrazone tautomerism is found to be more favored in paranitrophenyl azophenol but is least favored in paramethoxyphenyl azophenol (vide infra). ${ }^{8,9}$ To understand the tautomerism of these chromogenic azocalix[4]arenes

(5) (a) Shu, C.-M.; Lin, W.-L.; Lee, G.-H.; Peng, S.-M.; Chung, W. S. J. Chin. Chem. Soc. 2000, 47, 173. (b) Compound 2 was prepared in a five-step synthetic sequence, see: Ho, Z.-C.; Ku, M.-C.; Shu, C.-M.; Lin, L.-G. Tetrahedron 1996, 52, 13189. (c) Shu, C.-M.; Yuan, T.-S.; Ku, M.-C.; Ho, Z.-C.; Liu, W.-C.; Tang, F.-S.; Lin, L.-G. Tetrahedron, 1996, 52, 9805. (d) Yeh, M.; Tang, F.; Chen, S.; Liu, W.; Lin, L.-G. J. Org. Chem. 1994, 59, 754 .

(6) For a procedure of hydroboration, see: Moran, J. K.; Georgiev, E. M.; Yordanov, A. T.; Mague, J. T.; Roundhill, D. M. J. Org. Chem. $\mathbf{1 9 9 4}, 59,5990$.

(7) For lower rim esterification of calix[4]arenes, see: (a) Chen, X.; Wai, C. M.; Fisher, D. R. U.S. Patent 6,075,130, 2000. (b) Casnati, A. Ting, Y.; Berti, D.; Fabbi, M.; Pochini, A.; Ungaro, R.; Sciotto, D.; Lombardo, G. G. Tetrahedron 1993, 49, 9815. (c) Chang, S.-K.; Cho, I J. Chem. Soc., Perkin Trans. 1 1986, 211. (d) McKervey, M. A.; Seward, E. M.; Ferguson, G.; Ruhl, B.; Harris, S. J. J. Chem. Soc., Chem. Commun. 1985, 388. (e) Arduini, A.; Pochini, A.; Reverberi, S.; Ungaro, R.; Andreetti, G. D.; Ugozzoli, F. Tetrahedron 1986, 42, 2089. (f) Arimura, T.; Kubota, M.; Matsuda, T.; Manabe, O.; Shinkai, S. Bull. Chem. Soc. Jpn. 1989, 62, 1674.

(8) For some of the rare examples reporting complexation between azo groups on calix[4]arenes and transition metal ions see: (a) Nomura, E.; Taniguchi, H.; Otsuji, Y. Bull. Chem. Soc. Jpn. 1993, 66, 3797. (b) Nomura, E.; Taniguchi, H.; Tamura, S. Chem. Lett. 1989, 1125. (c) References 2g and 2h. (d) Deligöz, H.; Erdem, E. Solvent Ext. Ion Exch. 1997, $15,811$.

(9) (a) Kishimoto, S.; Kitahara, S.; Manabe, O.; Hiyama, H. J. Org. Chem. 1978, 43, 3882. (b) Shinkai, S.; Araki, K.; Shibata, J.; Tsugawa, D.; Manabe, O. Chem. Lett. 1989, 931. (c) Joshi, H.; Kamounah, F. S.; van der Zwan, G.; Gooijer, C.; Antonov, L. J. Chem. Soc., Perkin Trans. $22001,2303$. 

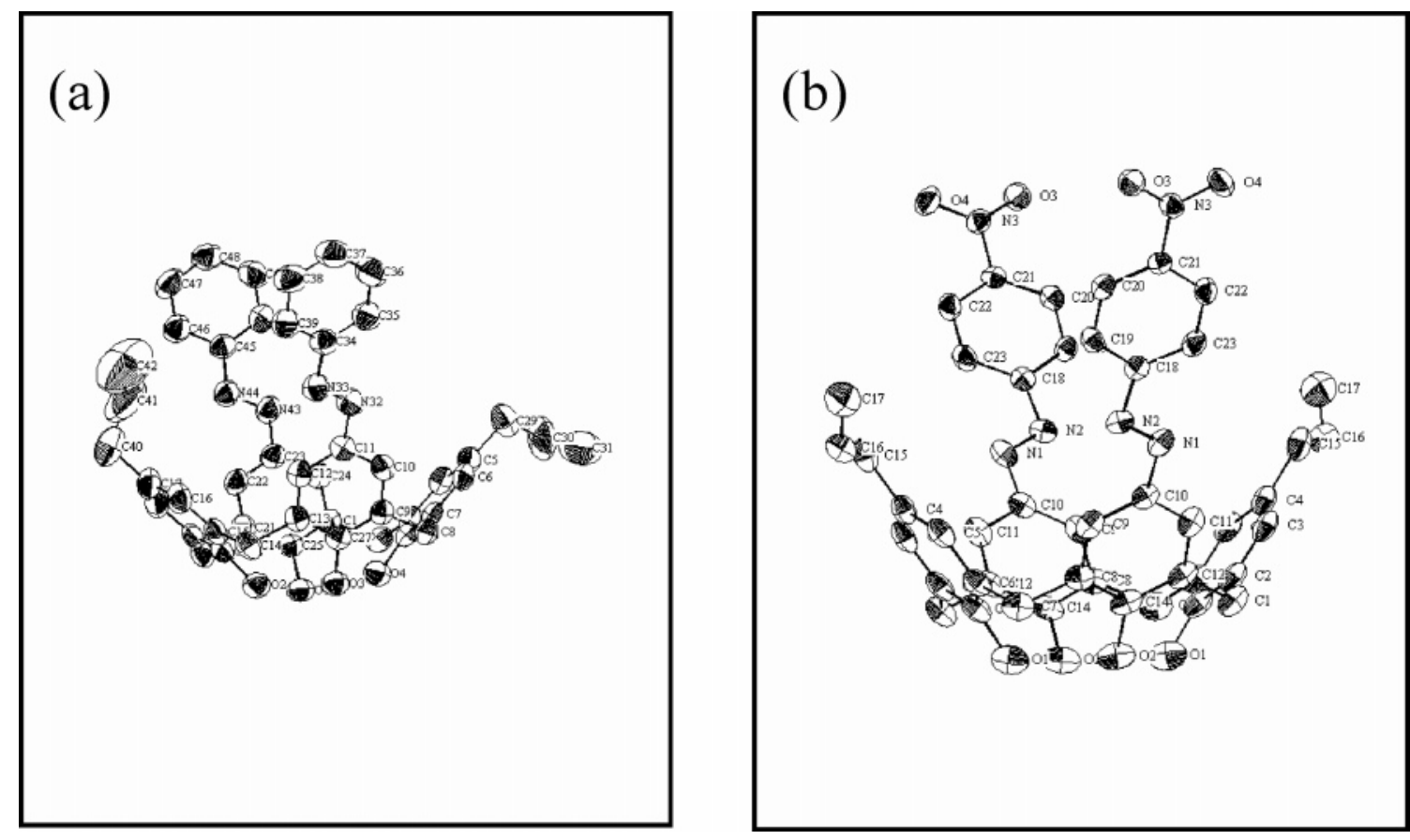

FIGURE 1. X-ray crystallographic structures of calix[4]arenes (a) 3a and (b) 3c.

\section{SCHEME 1. Synthetic Pathways for Chromoionophores $3 a-c$ and $4 a^{-} \mathbf{c}^{a}$}
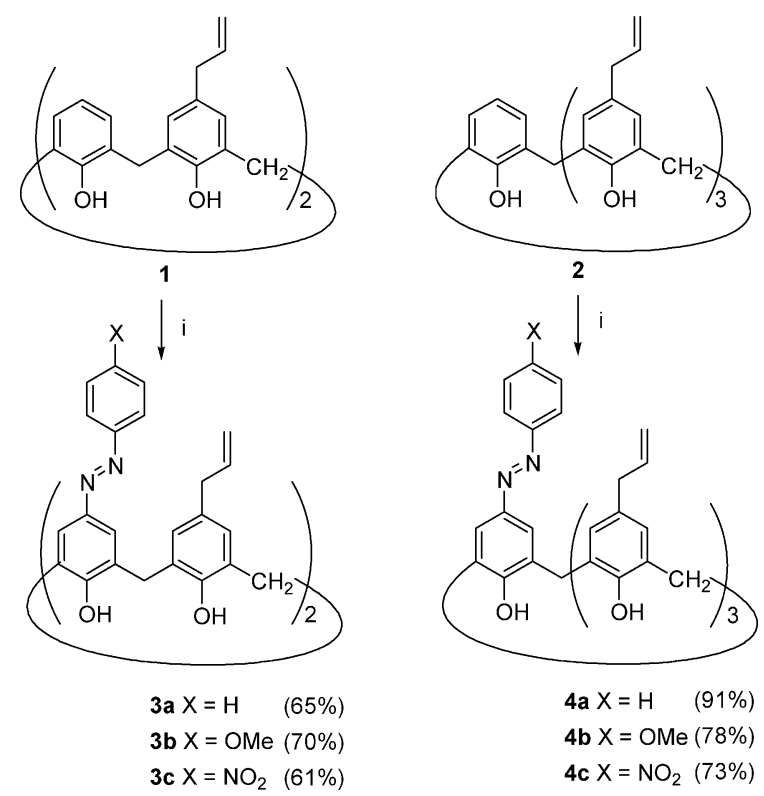

${ }^{a}$ Reagents and conditions: (i) $p$-X-aniline/acetone, $\mathrm{NaNO}_{2} / 4 \mathrm{M}$ $\mathrm{HCl}$, pyridine, $0^{\circ} \mathrm{C}, 1 \mathrm{~h}$.

$\mathbf{3 a}-\mathbf{c}, \mathbf{4 a}-\mathbf{c}$, and $\mathbf{5 a}, \mathbf{b}$, their UV/vis spectra in $\mathrm{CH}_{3} \mathrm{CN}$ and in $\mathrm{CHCl}_{3}$ were inspected first. As expected, there were bathochromic shifts in $\lambda_{\max }$ when piperidine $(10 \mu \mathrm{M})$ was added to the azocalix[4]arenes $3 \mathbf{a}-\mathbf{c}, \mathbf{4 a}-\mathbf{c}$, and $\mathbf{5 a}, \mathbf{b}(10-20 \mu \mathrm{M}$ in chloroform, Figure $2 \mathrm{a}-\mathrm{c})$; however, these changes in spectra were fully reversible, as the addition of $\mathrm{HCl}$ to these solutions reversed the color change. It should be noted that the shifts in $\lambda_{\max }$ were small for $\mathbf{3 a}, \mathbf{b}, \mathbf{4 a}, \mathbf{b}$, and $\mathbf{5 a}, \mathbf{b}$ up to $40 \mathrm{mM}$ of added $\mathrm{NaOH}$, whereas large shifts in $\lambda_{\max }$ were observed for the $p$-nitrophenyl azocalixarenes $3 \mathbf{c}-\mathbf{4 c}$ when the same amount of $\mathrm{NaOH}$ was added. This is due to the ease in

\section{SCHEME 2. Synthetic Pathways for Chromoionophores 5a,b and $6 \mathrm{~b}, \mathrm{c}^{a}$}

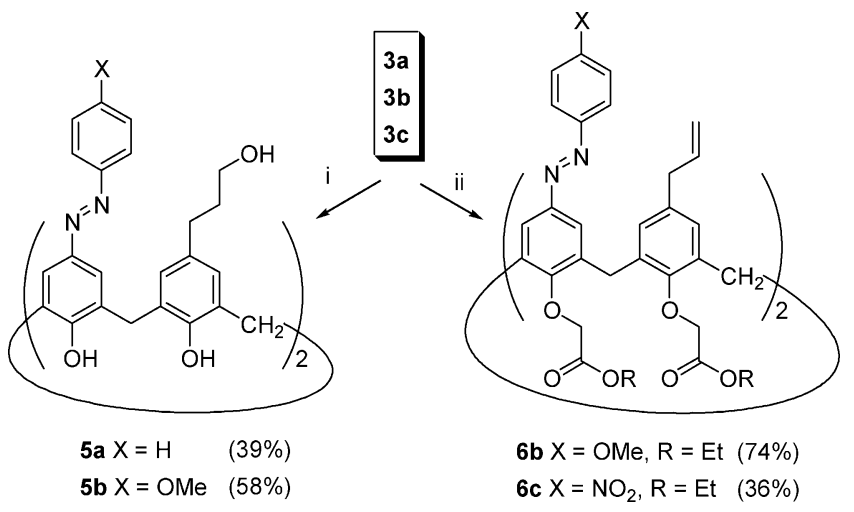

${ }^{a}$ Reagents and conditions: (i) (1) 4 equiv of $\mathrm{BH}_{3} \cdot \mathrm{THF}$, THF, rt, $1.5 \mathrm{~h}$; (2) $\mathrm{NaOH}, \mathrm{H}_{2} \mathrm{O}_{2}$, rt, $1.5 \mathrm{~h}$. (ii) $\mathrm{NaH}$ (20 equiv), $\mathrm{BrCH}_{2} \mathrm{CO}_{2} \mathrm{Et}$ (20 equiv), THF, $50{ }^{\circ} \mathrm{C}, 8 \mathrm{~h}$.

deprotonation of the lower rim hydroxy groups in $\mathbf{3 c}-$ 4c by a base, which favors the quinone forms. Lower rim etherification of these azocalixarenes should block this tautomerism pathway, and small change in spectra was expected. Indeed, the UV/vis spectrum stays almost the same when piperidine $(10 \mu \mathrm{M})$ was added to the solution of $6 \mathbf{b}$ (Figure 2d).

We next investigated the affinity of these upper rim allyl- and azo-coupled calix[4] arenes $(\mathbf{3 a}-\mathbf{c}, \mathbf{4 a}-\mathbf{c}, \mathbf{5 a}, \mathbf{b}$, and $6 \mathbf{b}, \mathbf{c})$ for a series of transition metal ions $\left(\mathrm{Cr}^{3+}, \mathrm{Ni}^{2+}\right.$, $\mathrm{Cu}^{2+}, \mathrm{Cd}^{2+}, \mathrm{Hg}^{2+}$, and $\left.\mathrm{Pb}^{2+}\right)$ and group $\mathrm{I}\left(\mathrm{Li}^{+}\right.$and $\left.\mathrm{Na}^{+}\right)$ and group II $\left(\mathrm{Ca}^{2+}\right.$ and $\left.\mathrm{Ba}^{2+}\right)$ metal ions in a methanolchloroform $(\mathrm{v} / \mathrm{v}=1 / 399)$ cosolvent. Table 1 summarizes the bathochromic shifts of azocalix[4] arenes $\mathbf{3 a}-\mathbf{c}, \mathbf{4 a}-$ $\mathbf{c}, \mathbf{5 a}, \mathbf{b}$, and $\mathbf{6 b}, \mathbf{c}$ after adding 5 equiv of metal perchlorates. Only minor changes in UV/vis spectra were seen when 5 equiv of group I and II metal ions were added to 3b (Figure 3a), whereas marked hyperchromic shifts 

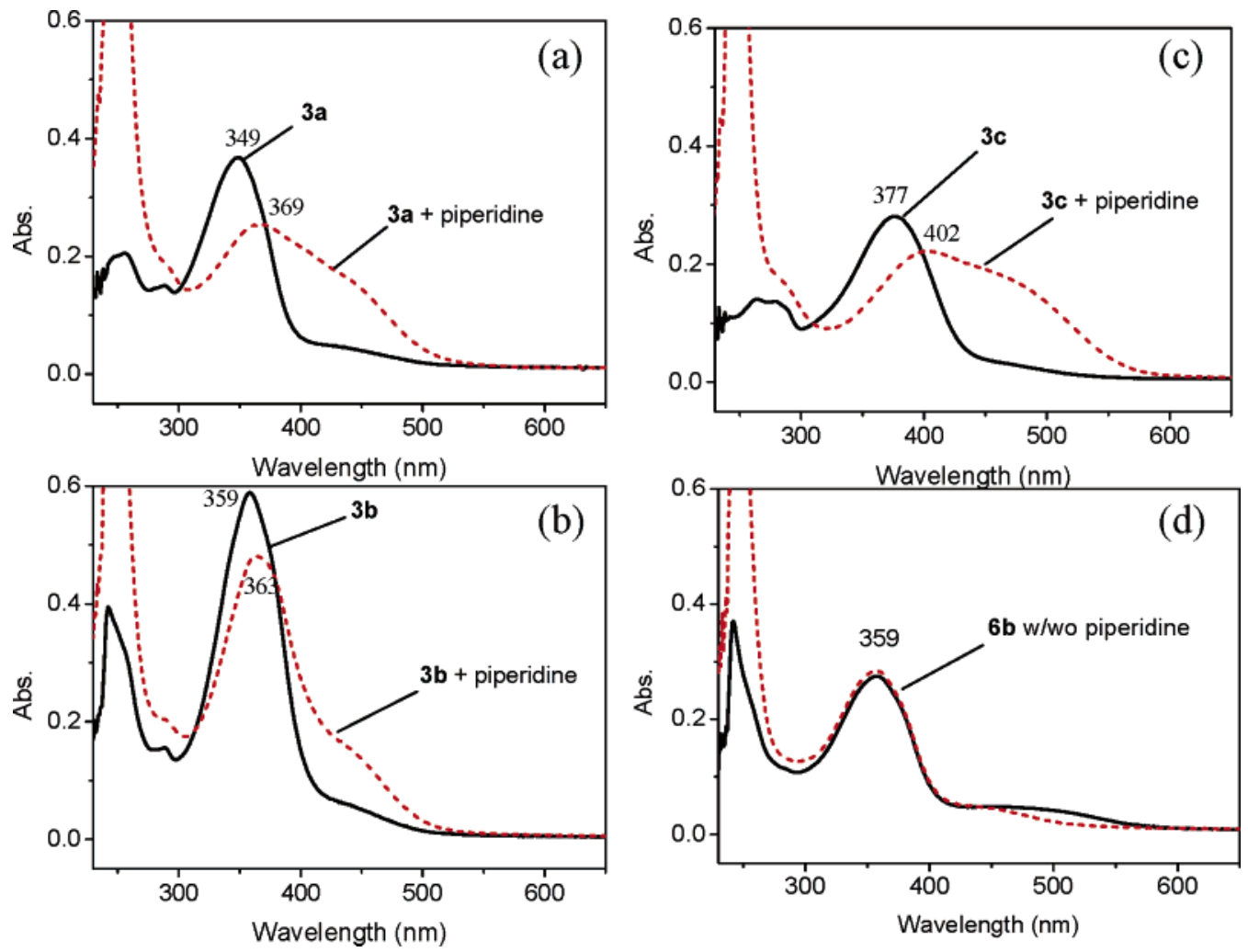

FIGURE 2. UV/vis spectra of azocalix[4]arenes $(10 \mu \mathrm{M})$ in chloroform (solid line) and in the presence of $10 \mu \mathrm{M}$ of piperidine (dashed line) (a) $\mathbf{3 a}$, (b) $\mathbf{3 b}$, (c) $\mathbf{3 c}$, and (d) $\mathbf{6 b}$.

TABLE 1. Bathochromic Shifts $\left(\Delta \lambda_{\max } / \mathrm{nm}\right)$ of Azocalix[4]arenes $3 a-c, 4 a-c, 5 a, b$, and $6 \mathrm{~b}, \mathrm{c}$ by the Addition of $50 \mu \mathrm{M}$ Metal Perchlorates in a Methanol-Chloroform (v/v = 1/399) Cosolvent ${ }^{a}$

\begin{tabular}{|c|c|c|c|c|c|c|c|c|c|c|c|}
\hline \multirow[b]{2}{*}{ compd } & \multirow[b]{2}{*}{$\lambda_{\max }, \mathrm{nm}$} & \multicolumn{10}{|c|}{$\Delta \lambda_{\max } / \mathrm{nm}^{b}$ after adding metal perchlorates } \\
\hline & & $\mathrm{Li}^{+}$ & $\mathrm{Na}^{+}$ & $\mathrm{Ca}^{2+}$ & $\mathrm{Ba}^{2+}$ & $\mathrm{Cr}^{3+}$ & $\mathrm{Ni}^{2+}$ & $\mathrm{Cu}^{2+}$ & $\mathrm{Cd}^{2+}$ & $\mathrm{Hg}^{2+}$ & $\mathrm{Pb}^{2+}$ \\
\hline $\mathbf{3 a}$ & 348 & $143^{c}$ & $143^{c}$ & $142^{c}$ & 133 & 136 & 127 & 132 & 129 & 132 & 129 \\
\hline $\mathbf{3 b}$ & 359 & 159 & 159 & 161 & 161 & 162 & 164 & 162 & 161 & 161 & 162 \\
\hline $3 c$ & 377 & nc & $\mathrm{nc}$ & nc & $\mathrm{nc}$ & nc & nc & $\mathrm{nc}$ & $\mathrm{nc}$ & $\mathrm{nc}$ & $\mathrm{nc}$ \\
\hline $4 a$ & 349 & $\mathrm{nc}$ & $\mathrm{nc}$ & $141^{c}$ & $141^{c}$ & $134^{c}$ & $140^{c}$ & $140^{c}$ & 128 & 131 & 128 \\
\hline $4 b$ & 359 & 159 & 159 & 160 & 161 & 161 & 162 & 159 & 160 & 162 & 161 \\
\hline $4 c$ & 377 & nc & $\mathrm{nc}$ & $\mathrm{nc}$ & $\mathrm{nc}$ & $\mathrm{nc}$ & $\mathrm{nc}$ & nc & $\mathrm{nc}$ & $\mathrm{nc}$ & $\mathrm{nc}$ \\
\hline $5 \mathbf{a}$ & 347 & $130^{c}$ & 130 & 130 & 130 & 135 & 128 & 133 & 130 & 138 & 130 \\
\hline $\mathbf{5 b}$ & 359 & 159 & 159 & 160 & 161 & 162 & 161 & 160 & 161 & 160 & 161 \\
\hline & & & $\rho d$ & -2 & 0 & -3 & -1 & -1 & 0 & -2 & -2 \\
\hline $6 \mathrm{~b}$ & 359 & $-5^{d}$ & $-6^{d}$ & $134^{e}$ & $137^{e}$ & $131^{e}$ & $136^{e}$ & $136^{e}$ & $136^{e}$ & $125^{e}$ & $136^{e}$ \\
\hline $6 c$ & 370 & -22 & -27 & -17 & -15 & -17 & -18 & -15 & -4 & -8 & -2 \\
\hline
\end{tabular}

${ }^{a}$ Concentration for $\mathbf{3 a}-\mathbf{c}$ and $\mathbf{5 a}, \mathbf{b}$ was $10 \mu \mathrm{M}$ and that for $\mathbf{4 a}-\mathbf{c}$ was $20 \mu \mathrm{M}$, where nc denotes no detectable change in $\lambda_{\text {max }}$ upon metal ion complexation. ${ }^{b} \Delta \lambda_{\max }=\lambda_{\text {complex }}-\lambda_{\max }$ (free host). ${ }^{c}$ Absorption at this $\lambda_{\text {complex }}$ was below $0.02 .{ }^{d}$ Besides the blue shift of the $359 \mathrm{~nm}$ band, there is a weak absorption band around $450 \sim 525 \mathrm{~nm} .{ }^{e}$ An apparent peak at $\lambda_{\max }$ around $485 \sim 495 \mathrm{~nm}$ was observed.

were observed for transition metal ions, especially for $\mathrm{Hg}^{2+}, \mathrm{Cr}^{3+}$, and $\mathrm{Cu}^{2+}$ ions (Figure 3b). It is noteworthy that $10 \mu \mathrm{M}$ piperidine alone gave very little color change in $\mathbf{3 b}$; however, the light yellowish solution of $\mathbf{3} \mathbf{b}$ turned into a bright red color upon complexation with $\mathrm{Hg}\left(\mathrm{ClO}_{4}\right)_{2}$, which is clearly visible to the naked eye (Figure 4). Surprisingly, no detectable changes in absorption spectra were observed for the very popular 4-(4-nitrophenyl)azophenol calix[4]arenes $\mathbf{3 c}$ and $\mathbf{4 c}$ when 10 different metal ions were added in excess separately (see Table 1). These observations imply that there is a subtle balance between metal complexation-induced release of protons from the azophenols to the quinone-hydrazone tautomer. ${ }^{2,8,9}$ Moreover, the para substituent of the phenyl azo group must have a strong influence on the tautomerism of azo/hydrazone, thus showing very diverse $\lambda_{\max }$ shifts. A picture of metal-ion- or base-induced tautomerism of the para-substituted phenyl azophenol is shown in Scheme 3.

Upon interacting with $\mathrm{Hg}\left(\mathrm{ClO}_{4}\right)_{2}$, the allyl- and azobased chromoionophore $\mathbf{3 b}$ in methanol-chloroform (v/v $=1 / 399)$ solution experienced a marked bathochromic shift in its $\lambda_{\max }$ as shown in Figure 5a. The absorption maximum at $359 \mathrm{~nm}$ gradually decreased in intensity with the formation of a new absorption band at ca. 520 $\mathrm{nm}\left(\Delta \lambda_{\max }=161 \mathrm{~nm}\right)$. Three isosbestic points at 263,285 , and $410 \mathrm{~nm}$ can be easily identified when difference absorption spectra analyse ${ }^{10}$ were used for the titration spectra of $\mathbf{3 b}$ by $\mathrm{Hg}\left(\mathrm{ClO}_{4}\right)_{2}$ (Figure $5 \mathrm{~b}$ ). The spectra features in Figure 5 are consistent with a 1:1 binding 

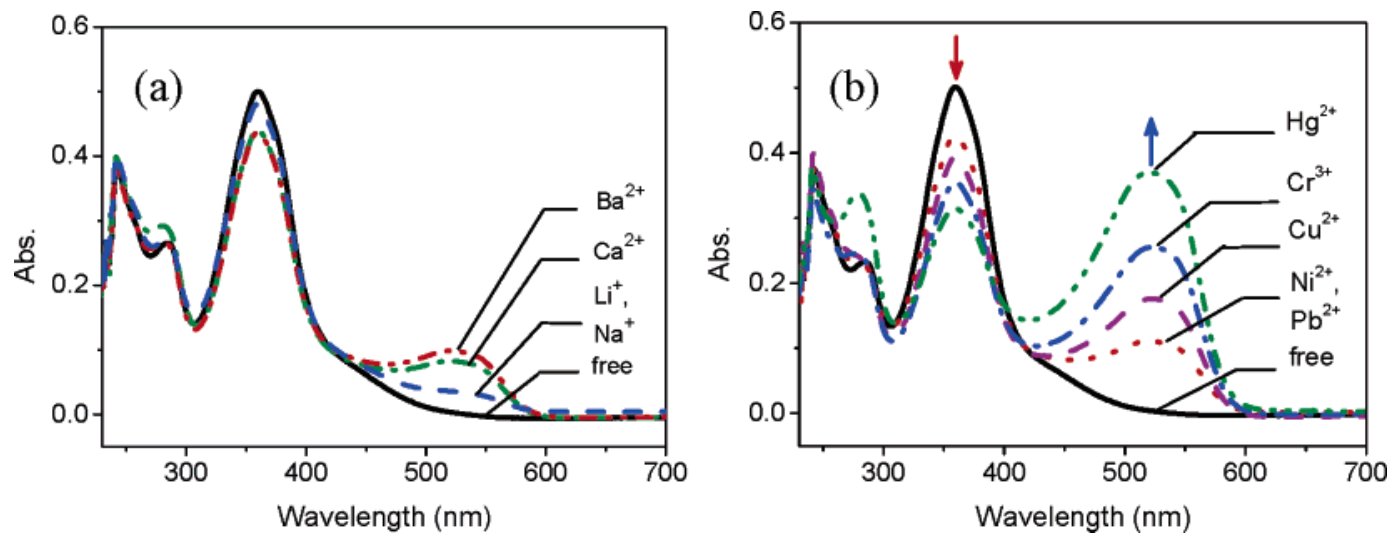

FIGURE 3. UV/vis spectra of $\mathbf{3 b}(10 \mu \mathrm{M})$ before and after adding a $50 \mu \mathrm{M}$ concentration of various metal perchlorates in a methanol-chloroform (v/v = 1/399) cosolvent: (a) $\mathrm{Li}^{+}, \mathrm{Na}^{+}, \mathrm{Ca}^{2+}$, and $\mathrm{Ba}^{2+}$ ions; (b) $\mathrm{Hg}^{2+}, \mathrm{Cr}^{3+}, \mathrm{Cu}^{2+}, \mathrm{Ni}^{2+}$, and $\mathrm{Pb}^{2+}$ ions. The absorption band at $359 \mathrm{~nm}$ decreased in intensity with the formation of a new band at ca. $520 \mathrm{~nm}$.

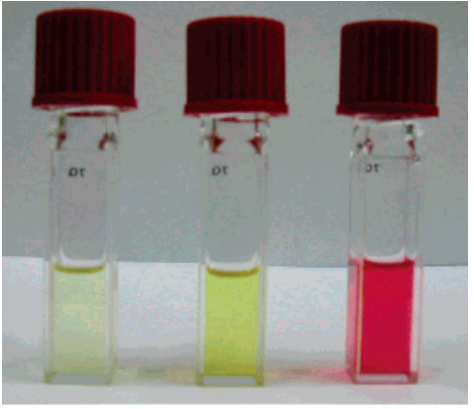

(a)

(c)
FIGURE 4. Colors of (a) $3 \mathbf{b}(10 \mu \mathrm{M})$ in a methanolchloroform (v/v $=1 / 399)$ cosolvent, (b) $\mathbf{3 b}$ after adding $10 \mu \mathrm{M}$ piperidine, and (c) $\mathbf{3 b}$ after adding 5 equiv of $\mathrm{Hg}\left(\mathrm{ClO}_{4}\right)_{2}$.

SCHEME 3. Tautomerism of the Azophenol and Quinone-hydrazone<smiles>[X]c1ccc(N=Nc2ccc(O)cc2)cc1</smiles><smiles>[R16]O[18OH]</smiles><smiles></smiles><smiles>C[CH-]C</smiles><smiles>O=C1C=CC(N=Nc2ccc(N([O-])[O-])cc2)C=C1</smiles>

Quinone-Hydrazone

B (when $\mathrm{X}=\mathrm{NO}_{2}$ )

ratio between calix[4]arene $\mathbf{3 b}$ and $\mathrm{Hg}^{2+}$ ion. Further support of the 1:1 binding ratio comes from a Job's plot experiment, ${ }^{11}$ where the absorptions of the complex at $520 \mathrm{~nm}$ were plotted against molar fractions of $\mathbf{3 b}$ under the conditions of an invariant total concentration. As a result, the concentration of $\mathbf{3} \mathbf{b} \cdot \mathrm{Hg}^{2+}$ complex approached a maximum when the molar fraction of $[\mathbf{3 b}] /([\mathbf{3 b}]+$ $\left[\mathrm{Hg}^{2+}\right]$ ) was about 0.5 (see Figure 6).

(10) (a) Difference absorption spectra analysis is a popular method used in biophysical and biochemical fields, see: Lyles, M. B.; Cameron, I. L. Biophys. Chem. 2002, 96, 53. (b) Three isosbestic points were reported in alizarine-modified $\beta$-CD: Aoyagi, T.; Nakamura, A.; Ikeda, H.; Ikeda, T.; Mihara, H.; Ueno, A. Anal. Chem. 1997, 69, 659.

(11) Connors, K. A. Binding Constants, Wiley: New York, 1987.

(a)

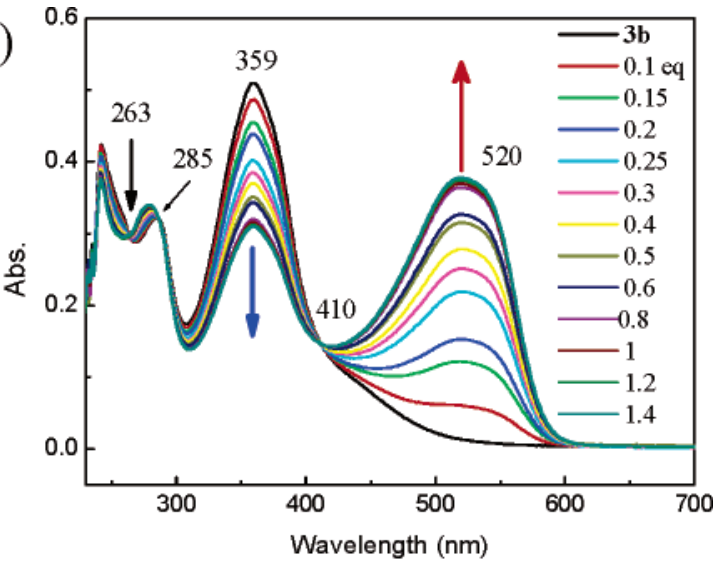

(b)

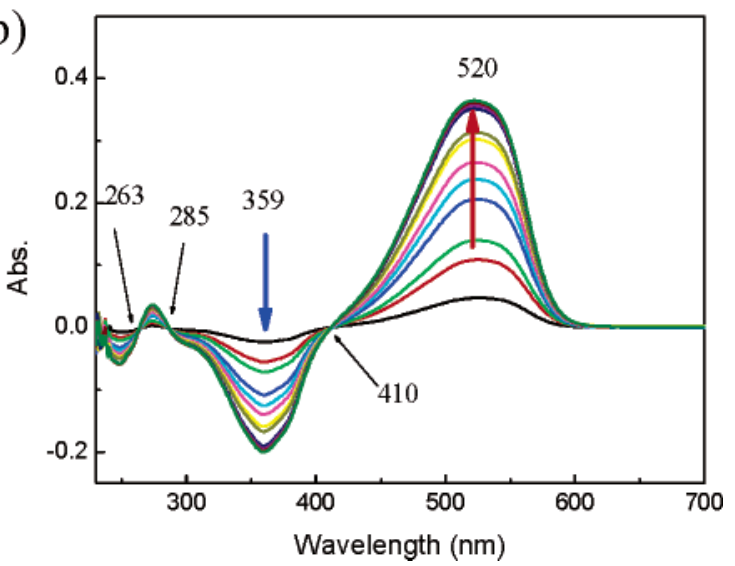

FIGURE 5. (a) Changes in the UV/vis spectra of $\mathbf{3 b}(10 \mu \mathrm{M})$ upon titration by $\mathrm{Hg}\left(\mathrm{ClO}_{4}\right)_{2}$ in a methanol-chloroform $(\mathrm{v} / \mathrm{v}=$ 1/399) cosolvent, where the concentration of $\mathrm{Hg}\left(\mathrm{ClO}_{4}\right)_{2}$ varies from 1 to $14 \mu \mathrm{M}$, and (b) the difference absorption spectra of a.

Since very few changes in UV/vis spectra were found when azocalix[4]arenes $\mathbf{3 a}-\mathbf{c}, \mathbf{4 a}-\mathbf{c}$, and $\mathbf{5 a}, \mathbf{b}$ were treated with excess group I and II metal ions, their association constants were not determined. Among the eight upper rim azo-modified calix[4]arenes, only $\mathbf{3 b}, \mathbf{4 b}$, and $\mathbf{5 b}$ showed marked bathochromic shifts upon complexation with transition metal ions $\left(\mathrm{Cr}^{3+}, \mathrm{Ni}^{2+}, \mathrm{Cu}^{2+}\right.$, and $\left.\mathrm{Hg}^{2+}\right)$; therefore, their 1:1 association constants were determined on the basis of Benesi-Hilderbrand plots (see 


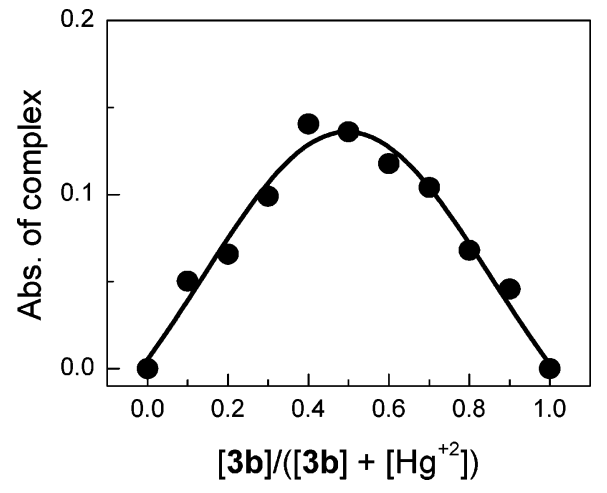

FIGURE 6. Job's plot of a 1:1 complex of $\mathbf{3 b}$ and $\mathrm{Hg}^{2+}$ ion, where the absorption at $520 \mathrm{~nm}$ was plotted against the mole fraction of $\mathbf{3 b}$ at an invariant total concentration of $2 \times 10^{-5}$ $\mathrm{M}$ in a $\mathrm{MeOH} / \mathrm{CHCl}_{3}(\mathrm{v} / \mathrm{v}=1 / 19)$ cosolvent.

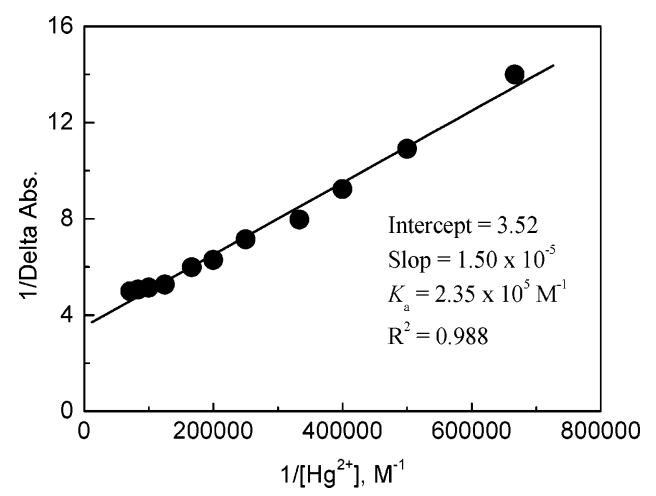

FIGURE 7. Benesi-Hilderbrand plot of $\mathbf{3 b}$ with $\mathrm{Hg}\left(\mathrm{ClO}_{4}\right)_{2}$.

TABLE 2. Association Constants $\left(M^{-1}\right)$ in Log Scale $\left(\log K_{\mathrm{a}}\right)$ Based on UV/vis Titrations of Ionophores 3a,b, 4a,b, 5a,b, and 6b,c with Transition Metal Ion Perchlorates in a Methanol-Chloroform $(v / v=1 / 399)$ Cosolvent at $25{ }^{\circ} \mathrm{C}$

\begin{tabular}{|c|c|c|c|c|}
\hline \multirow[b]{2}{*}{ compd } & \multicolumn{4}{|c|}{$\log K_{\mathrm{a}},\left(\mathrm{M}^{-1}\right)$} \\
\hline & $\mathrm{Cr}^{3+}$ & $\mathrm{Ni}^{2+}$ & $\mathrm{Cu}^{2+}$ & $\mathrm{Hg}^{2+}$ \\
\hline $3 \mathbf{a}$ & a & & & 5.17 \\
\hline $\mathbf{3 b}$ & 4.85 & 4.82 & 5.25 & 5.37 \\
\hline $4 a$ & & $\mathrm{a}$ & $\mathrm{a}$ & 4.70 \\
\hline $4 b$ & 4.57 & $\mathrm{a}$ & a & 4.80 \\
\hline $5 \mathbf{a}$ & $\mathrm{a}$ & & & 4.73 \\
\hline $5 b$ & 4.98 & 4.92 & 4.94 & 5.07 \\
\hline $6 \mathbf{b}$ & 3.48 & $\mathrm{a}$ & a & 4.27 \\
\hline $6 c$ & $\stackrel{\mathrm{a}}{\mathrm{Li}^{+}}=4.07^{b}$ & $\stackrel{\mathrm{a}}{\mathrm{Na}^{+}}=4.37^{b}$ & a & $\mathrm{a}$ \\
\hline
\end{tabular}

${ }^{a}$ Association constant was not determined because the absorption differences of the complex were too small to be evaluated. ${ }^{b}$ Association constants for group I metal ions were measurable from UV/vis titrations.

Experimental Section). ${ }^{12}$ A typical plot for $\mathbf{3 b}$ and $\mathrm{Hg}$ $\left(\mathrm{ClO}_{4}\right)_{2}$ is shown in Figure 7, and data for all association constants $\left(K_{\mathrm{a}}\right.$ in log scale) are summarized in Table 2 . It is noteworthy that most of the $K_{\mathrm{a}}$ f for phenyl azophenols $\mathbf{3 a}-\mathbf{5 a}$ and para-nitrophenyl azophenols $3 \mathbf{c}-\mathbf{4 c}$ were not determined because their metal-ion-induced absorption changes were mostly too small to be evaluated except for $\mathrm{Hg}^{2+}$ ion. In contrast, the para-methoxyphenyl azophenol 2703. series $(\mathbf{3 b}, \mathbf{4 b}$, and $\mathbf{5 b})$ showed very high sensitivity and selectivity toward transition metal ions, especially $\mathrm{Hg}^{2+}$ ion. The relative binding strengths of these chromogenic ionophores toward $\mathrm{Hg}^{2+}$ ion were determined to be $\mathbf{3 b}>$ $3 a>5 b>4 b>5 a \sim 4 a>6 b \gg 3 c-6 c$. Furthermore, the selectivity trends of $\mathbf{3 b}$ toward cations were determined to be $\mathrm{Hg}^{2+}>\mathrm{Cu}^{2+}>\mathrm{Cr}^{3+}>\mathrm{Ni}^{2+} \gg\left(\mathrm{Pb}^{2+}, \mathrm{Cd}^{2+}\right.$, $\mathrm{Ca}^{2+}, \mathrm{Ba}^{2+}, \mathrm{Na}^{+}$, and $\mathrm{Li}^{+}$) as shown in Figure 3 and Table 2.

The hypsochromic shift of $\lambda_{\max }(359 \mathrm{~nm})$ of $\mathbf{6 c}$ by 22 and $27 \mathrm{~nm}$ when binding with $\mathrm{Li}^{+}$and $\mathrm{Na}^{+}$, respectively, implies that $\mathbf{6 c}$ uses the lower rim tetra ether-esters to bind metal ions (Figures S-8 and S-9, Supporting Information), which is consistent with those reported by Kim for lower rim crown-ether-modified azocalix[4] arenes. . $^{2 \mathrm{k}, \mathrm{l}}$ When complexed with metal ion, the oxygen atoms of the lower rim ether-ester units of $\mathbf{6 c}$ are positively polarized; therefore, the excited states are more strongly destabilized by cations than the ground states, ${ }^{1 \mathrm{a}, 13}$ thus causing blue shifts of the $\lambda_{\max }$ band. Had the lower rim etheresters been the only binding sites, one would have observed similar chromogenic behaviors for the homologue azocalix[4]arenes $\mathbf{6 b}$ and $\mathbf{6 c}$, because their only structural difference is in the upper rim: para-methoxyphenyl for $\mathbf{6 b}$ and para-nitrophenyl for $\mathbf{6 c}$. However, a quite different UV band splitting was observed when $\mathbf{6 b}$ complexed with metal ions, where both a small hypsochromic shift and a large bathochromic shift in $\lambda_{\max }$ appeared concomitantly (Table 1). Furthermore, UV/vis titration of $6 \mathbf{b}$ by $\mathrm{Hg}^{2+}$ showed two $\lambda_{\max }$ around 479 and $492 \mathrm{~nm}$, which implies that $\mathrm{Hg}^{2+}$ may be entrapped in two different binding sites (see Figure S-6, Supporting Information). All these results imply that para-methoxyphenyl azophenol is capable of binding metal ions through its quinone-hydrazone tautomer; therefore, marked bathochromic shifts are observed.

To gain insight into the structures of complex formation of these chromogenic ionophores, we also carried out ${ }^{1} \mathrm{H}$ NMR titration experiments. Figure 8 shows the ${ }^{1} \mathrm{H}$ NMR spectra of $3 \mathbf{b}(5 \mathrm{mM})$ in methanol- $d_{4} / \mathrm{CDCl}_{3}(\mathrm{v} / \mathrm{v}=$ 1:3) solution in the presence of different amounts of $\mathrm{Hg}^{2+}$ ion. Three important features were observed from the ${ }^{1} \mathrm{H}$ NMR spectra: (1) Large variation in chemical shifts is experienced by protons on the para-methoxyphenyl and azophenol groups; that is, protons $\mathrm{H}_{\mathrm{f}}$ and $\mathrm{H}_{\mathrm{a}}$ on both ends of the azo groups move $0.10 \mathrm{ppm}$ upfield to $\mathrm{H}_{\mathrm{f}}$ and $\mathrm{H}_{\mathrm{a}}$ upon complexation with $\mathrm{Hg}^{2+}$ (see inset of Figure 8). (2) Signal intensities of protons on the allyl groups (namely, $\mathrm{H}_{\mathrm{c}}, \mathrm{H}_{\mathrm{d}}$, and $\mathrm{H}_{\mathrm{e}}$ ) decreased dramatically (to less than $30 \%$ of its original) in the presence of 2.2 equiv of $\mathrm{Hg}^{2+}$ ion. (3) The vaguely seen broad singlets of the methylene bridges around $\delta 3.5-4.5$ in free ligand $\mathbf{3 b}$ were shifted upfield to $\delta$ 2-4 upon complexation with $\mathrm{Hg}^{2+}$ and became sharp and complicated.

It is conceivable that these changes in chemical shifts and signal intensities are due to coordination of the $\mathrm{Hg}^{2+}$ ion to the upper rim azo groups (in its hydrazone form) and that strong dipolar interactions occur between the $\mathrm{Hg}^{2+}$ ion and the nearby allyl groups. This binding mode of the complex not only explains the changes in chemical shifts but also explains why the allyl signals diminish

(13) Alternatively, metal ions may stabilize the ground states more than the excited states, thus causing a hypsochromic shift of $6 \mathbf{c}$. 


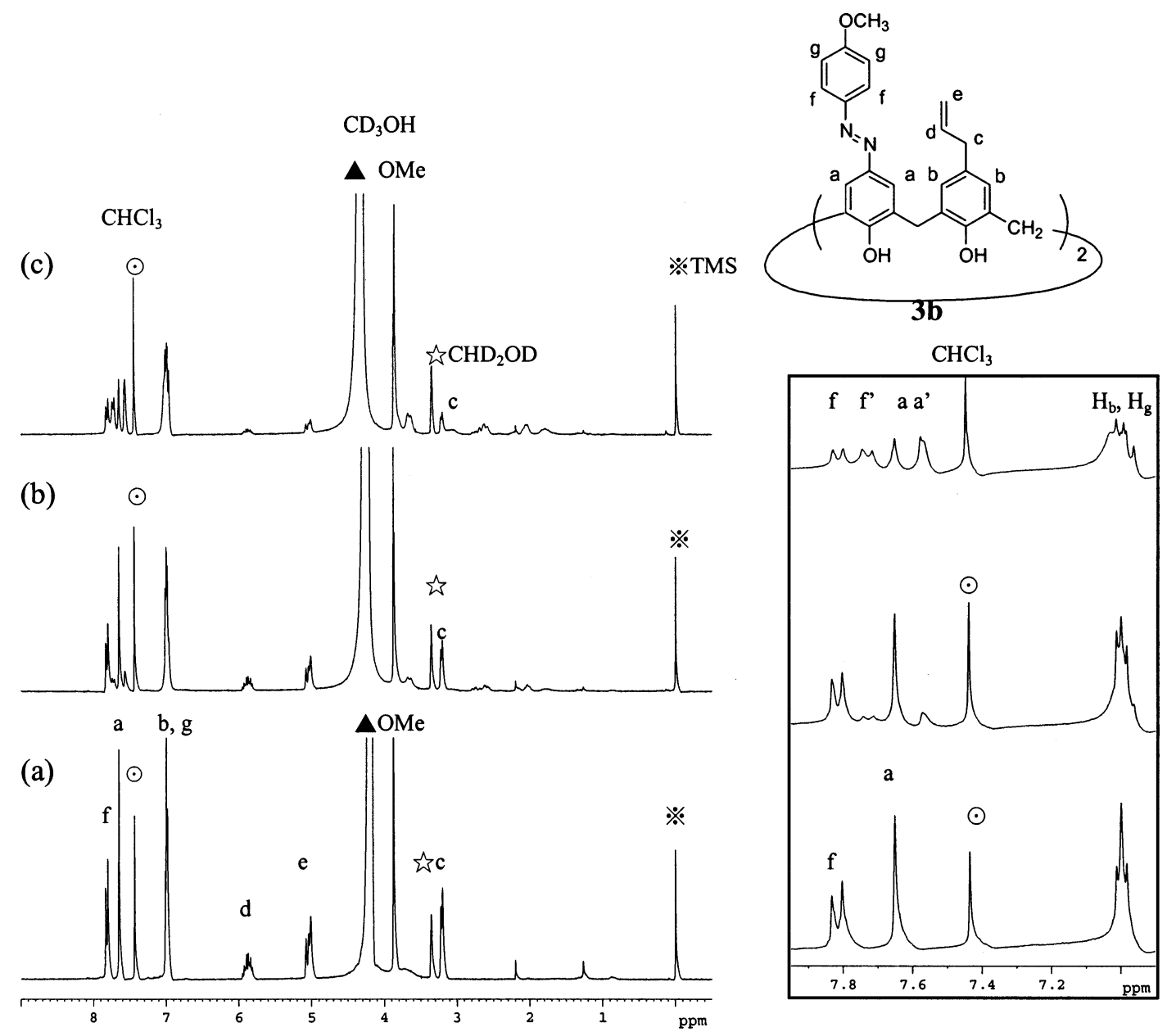

FIGURE 8. ${ }^{1} \mathrm{H}$ NMR spectra of compound $\mathbf{3 b}(5.0 \mathrm{mM})$ in a methanol- $d_{4} / \mathrm{CDCl}_{3}(1: 3)$ solution in the presence of different amounts of $\mathrm{Hg}\left(\mathrm{ClO}_{4}\right)_{2}$ : (a) 0 , (b) $5.56 \mathrm{mM}$ (1.1 equiv), and (c) $11.1 \mathrm{mM}$ (2.2 equiv). The inset on the right is an expanded region of $\delta 6.9$ to 8.0, where $\mathrm{H}_{\mathrm{f}}$ and $\mathrm{H}_{\mathrm{a}}$ were shifted upfield when 2.2 equiv of $\mathrm{Hg}^{2+}$ was added.

when 2 equiv of $\mathrm{Hg}^{2+}$ ion was added (Figure 8c) since it is well-known that spin-lattice relaxation time $\left(T_{1}\right)$ is greatly shortened by the existence of a nearby paramagnetic species such as an $\mathrm{Hg}^{2+}$ ion. ${ }^{14}$ The role of $p$-methoxy in the arylazo group is vital here because it helps to donate electrons toward the azo group through resonance, which reinforces the hydrazone that is formed through deprotonation of the azophenol to quinone-hydrazone (structure $\mathbf{A}$ in Scheme 3).

Inspecting the data reported in Table 2, one may readily find that calix[4]arenes with two upper rim azo groups on a face-to-face positions (e.g., $\mathbf{3 a}, \mathbf{b}$ and $\mathbf{5 a}, \mathbf{b}$ ) give higher association constants toward transition metal ions than those with only one upper rim azo and three allyl groups (e.g., 4a,b). Furthermore, upper rim allyl groups do not seem to have been involved in the binding of metal ions; they behave like bystanders because no change in chemical shifts was observed upon metal ion complexation. On the basis of all the information available for the metal complexes of these upper rim azo-

(14) For references about the influence of $T_{1}$ by paramagnetic species, see: (a) Lambert, B.; Jacques, V.; Desreux, J. F. In Calixarenes for Separations; Lumetta, G. J., Rogers, R. D., Gopalan, A. S., Eds.; American Chemical Society: Washington, DC, 2000; Chapter 13. (b) Wu, G.; Jiang, W.; Lamb, J. D.; Bradshaw, J. S.; Izatt, R. M. J. Am. Chem. Soc. 1991, 113, 6538. (c) Gutsche, C. D.; Iqbal, M.; Alam, I. J. Am. Chem. Soc. 1987, 109, 4314.

\section{ChaRT 1. Possible Structure of the $\mathbf{3 b} \cdot \mathbf{H g}^{2+}$ Complex}

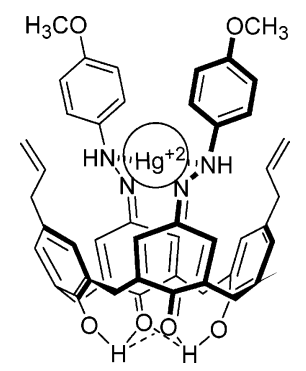

coupled calix[4]arenes, we propose a possible structure for the $\mathbf{3} \mathbf{b} \cdot \mathrm{Hg}^{2+}$ complex as shown in Chart 1 . It is noteworthy that these metal complexes are stabilized by two pairs of intramolecular hydrogen-bonding interactions between undissociated phenolic $\mathrm{OH}$ groups (of $p$-allylphenol) and neighboring dissociated phenolate anions. Further support of the $\mathbf{3 b} \cdot \mathrm{Hg}^{2+}$ complex structure comes from ${ }^{1} \mathrm{H}$ NMR and IR spectra (see Figures S-17 and S-18, Supporting Information).$^{15} \mathrm{NMR}$ spectra of free and $\mathrm{Hg}^{2+}$-complexed $\mathbf{3 b}$ using $\mathrm{CD}_{3} \mathrm{OH} / \mathrm{CDCl}_{3}(3 / 1)$ as a

(15) We thank one of the referees for suggestions of these NMR and IR experiments, which are very informative with respect to the structures of the complex. 
cosolvent were compared with those in Figure 8 using $\mathrm{CD}_{3} \mathrm{OD} / \mathrm{CDCl}_{3}(3 / 1)$ as a cosolvent. In $\mathrm{CD}_{3} \mathrm{OH} / \mathrm{CDCl}_{3}$ cosolvent, the phenolic protons of free host $\mathbf{3 b}$ showed a broad peak at $\delta 10.4$ that disappeared when complexed with 2 equiv of $\mathrm{Hg}^{2+}$ ion. On the other hand, two new signals around $\delta 7.82$ and 7.70 flanking the $\mathrm{Ha}$ and $\mathrm{Ha}^{\prime}$ signals appeared, which are quite likely to be signals of hydrazo protons and the intramolecular phenol protons (inset c, Figure S-17, Supporting Information). IR spectra of the $\mathbf{3 b} \cdot \mathrm{Hg}^{2+}$ complex were also consistent with the azophenol to quinone-hydrazone transformation (Figure S-18, Supporting Information).

\section{Summary and Conclusions}

All of these sensors are based on the well-known azobenzene structure, where one of the aromatic rings is an integrated part of the ion receptor. In the series of $\mathbf{3 b}-\mathbf{5 b}$, where 4-(4-methoxyphenyl)azophenol was used, high sensitivity of these chromoionophores for $\mathrm{Hg}^{2+}$ ion were found in a methanol-chloroform $(\mathrm{v} / \mathrm{v}=1 / 399)$ cosolvent. The $\mathrm{Hg}^{2+}$ ion detection gives rise to a large bathochromic shift in the absorption spectrum (from light yellow to bright red), which is clearly visible to the naked eye. The structure in Chart 1 provides a reasonable metal ion binding mode for the 4-phenyl- and 4-(4-methoxyphenyl)azophenol calix[4]arenes $\mathbf{3 a}, \mathbf{b}$ and $\mathbf{5 a}, \mathbf{b}$, respectively. No shifts in absorption spectra were observed for the very popular 4-(4-nitrophenyl)azophenol calix[4]arenes 3c4c when 10 different metal ions were added in excess. The lack of binding of $\mathbf{3 c}-\mathbf{4 c}$ may be explained by the predominant form of structure $\mathbf{B}$ in Scheme 3, in which the strongly electron-withdrawing nitro group prevents the formation of the hydrazone form; therefore, poor binding toward metal cations was observed. To the best of our knowledge, these upper rim allyl-, hydroxypropyl-, and azo-coupled calix [4] arenes are rare examples ${ }^{8}$ of such highly sensitive $\mathrm{Hg}^{2+}$ ion sensors based on azobenzenecalix [4]arene alone without further modification on the lower rims.

\section{Experimental Section}

The syntheses of 5,11-bisallylcalix[4] arene $1,^{5 \mathrm{c}} 5,11,17$ triallylcalix[4] arene $2{ }^{5 b}$ and 5,17-bisallyl-11,23-bis(phenylazo)calix[4]arenes $3 \mathbf{a}-\mathbf{c}^{5 c}$ have been reported by Lin et al., and we have followed their procedures for the preparation.

General Procedure for the Synthesis of Allylarylazo-25,26,27,28-tetrahydroxy calix [4]arenes $3 a^{-}-c^{5 c}$ and $\mathbf{4 a}-\mathbf{c}$. To an ice cold solution of $4.0 \mathrm{mmol}$ of para-substituted aniline in $5 \mathrm{~mL}$ of $4 \mathrm{~N} \mathrm{HCl}$ was added a solution of $0.41 \mathrm{~g}$ $(5.94 \mathrm{mmol})$ of $\mathrm{NaNO}_{2}$ in $5 \mathrm{~mL}$ of acetone, and the mixture was stirred for $30 \mathrm{~s}$. The combined solution was then added to another ice cold solution of $0.50 \mathrm{~g}(1.0 \mathrm{mmol})$ of $p$-diallyl- or $p$-triallylcalix[4]arenes (1 or 2) in $10 \mathrm{~mL}$ of pyridine to produce a colored solution. The reaction mixture was stirred for $1 \mathrm{~h}$ at $0{ }^{\circ} \mathrm{C}$ and then treated with $50 \mathrm{~mL}$ of $4 \mathrm{~N} \mathrm{HCl}$ to give a colored precipitate. The solid residue was purified by column chromatography with hexane and chloroform as an eluent and gave the corresponding bisarylazo or monoarylazo products in $61-$ $91 \%$ yields.

Data for 5,11,17-Triallyl-23-phenylazo-25,26,27,28tetrahydroxycalix[4]arene, 4a. The solid was eluted with hexane/chloroform $(\mathrm{v} / \mathrm{v}=2 / 1)$ and gave $0.55 \mathrm{~g}(91 \%)$ of an orange powder, mp $293-297{ }^{\circ} \mathrm{C}$ (dec): ${ }^{1} \mathrm{H}$ NMR $(300 \mathrm{MHz}$, $\left.\mathrm{CDCl}_{3}\right) \delta 10.21(\mathrm{~s}, 4 \mathrm{H}, \mathrm{OH}), 7.81(\mathrm{~d}, 2 \mathrm{H}, J=7.1 \mathrm{~Hz}), 7.68(\mathrm{~s}$, $2 \mathrm{H}), 7.51-7.42(\mathrm{~m}, 3 \mathrm{H}), 6.95-6.85(\mathrm{~m}, 6 \mathrm{H}), 5.92-5.82(\mathrm{~m}, 3 \mathrm{H})$, $5.08-4.99(\mathrm{~m}, 6 \mathrm{H}), 4.35-4.15(\mathrm{bs}, 4 \mathrm{H}), 3.70-3.40(\mathrm{bd}, 4 \mathrm{H})$, $3.21-3.16(\mathrm{~m}, 6 \mathrm{H}) ;{ }^{13} \mathrm{C} \mathrm{NMR}\left(75.4 \mathrm{MHz}, \mathrm{CDCl}_{3}\right) \delta 152.8\left(\mathrm{C}_{\mathrm{q}}\right)$, $151.9\left(\mathrm{C}_{\mathrm{q}}\right), 147.9\left(\mathrm{C}_{\mathrm{q}}\right), 146.9\left(\mathrm{C}_{\mathrm{q}}\right), 146.8\left(\mathrm{C}_{\mathrm{q}}\right), 137.4(\mathrm{CH}), 133.8$ $\left(\mathrm{C}_{\mathrm{q}}\right), 133.5\left(\mathrm{C}_{\mathrm{q}}\right), 130.3(\mathrm{CH}), 129.2(\mathrm{CH}), 129.0(\mathrm{CH}), 128.9(\mathrm{CH})$, $128.3\left(\mathrm{C}_{\mathrm{q}}\right), 128.0\left(\mathrm{C}_{\mathrm{q}}\right), 127.5\left(\mathrm{C}_{\mathrm{q}}\right), 124.0(\mathrm{CH}), 122.4(\mathrm{CH}), 115.7$ $\left(\mathrm{CH}_{2}\right), 115.6\left(\mathrm{CH}_{2}\right), 39.3\left(\mathrm{CH}_{2}\right), 31.8\left(\mathrm{CH}_{2}\right), 31.7\left(\mathrm{CH}_{2}\right)$; FABMS $m / z 649\left(\mathrm{M}+\mathrm{H}^{+}\right)$; HRMS $m / z$ calcd for $\mathrm{C}_{43} \mathrm{H}_{40} \mathrm{~N}_{2} \mathrm{O}_{4}$ 648.2990, found 648.3033. Anal. Calcd for $\mathrm{C}_{43} \mathrm{H}_{40} \mathrm{~N}_{2} \mathrm{O}_{4}$ : C, 79.59; H, 6.22; N, 4.32. Found: C, 79.38; H, 6.32; N, 4.53.

Data for 5,11,17-Triallyl-23-(p-methoxyphenyl)azo$\mathbf{2 5 , 2 6 , 2 7 , 2 8 - t e t r a h y d r o x y c a l i x}[4]$-arene, $4 \mathrm{~b}$. The solid was eluted with hexane/chloroform $(\mathrm{v} / \mathrm{v}=2 / 1)$ and gave $0.49 \mathrm{~g}$ (78\%) of a yellow powder, mp $260-262{ }^{\circ} \mathrm{C}(\mathrm{dec})$ : ${ }^{1} \mathrm{H}$ NMR $(300$ $\left.\mathrm{MHz} \mathrm{CDCl}_{3}\right) \delta 10.20(\mathrm{~s}, 4 \mathrm{H}, \mathrm{OH}), 7.85-7.81(\mathrm{~m}, 2 \mathrm{H}), 7.63(\mathrm{~s}$, $2 \mathrm{H}), 7.00-6.94(\mathrm{~m}, 4 \mathrm{H}), 6.87-6.84(\mathrm{~m}, 4 \mathrm{H}), 5.92-5.80(\mathrm{~m}, 3 \mathrm{H})$, $5.08-4.99(\mathrm{~m}, 6 \mathrm{H}), 4.35-4.15(\mathrm{bs}, 4 \mathrm{H}), 3.88(\mathrm{~s}, 3 \mathrm{H}), 3.70-3.40$ (bd, $4 \mathrm{H}), 3.21-3.16(\mathrm{~m}, 6 \mathrm{H}) ;{ }^{13} \mathrm{C} \mathrm{NMR}\left(\mathrm{CDCl}_{3}\right) \delta 161.6\left(\mathrm{C}_{\mathrm{q}}\right)$, $151.3\left(\mathrm{C}_{\mathrm{q}}\right), 147.5\left(\mathrm{C}_{\mathrm{q}}\right), 146.9\left(\mathrm{C}_{\mathrm{q}}\right), 137.5(\mathrm{CH}), 133.8\left(\mathrm{C}_{\mathrm{q}}\right), 133.6$ $\left(\mathrm{C}_{\mathrm{q}}\right), 129.2(\mathrm{CH}), 129.0(\mathrm{CH}), 128.8(\mathrm{CH}), 128.3\left(\mathrm{C}_{\mathrm{q}}\right), 128.0\left(\mathrm{C}_{\mathrm{q}}\right)$, $127.6\left(\mathrm{C}_{\mathrm{q}}\right), 124.3(\mathrm{CH}), 123.6(\mathrm{CH}), 115.6\left(\mathrm{CH}_{2}\right), 114.1(\mathrm{CH})$, $55.5\left(\mathrm{CH}_{3}\right), 39.3\left(\mathrm{CH}_{2}\right), 31.8\left(\mathrm{CH}_{2}\right), 31.7\left(\mathrm{CH}_{2}\right) ; \mathrm{FAB}-\mathrm{MS} \mathrm{m} / \mathrm{z}$ $679\left(\mathrm{M}+\mathrm{H}^{+}\right)$; HRMS m/z calcd for $\mathrm{C}_{44} \mathrm{H}_{42} \mathrm{~N}_{2} \mathrm{O}_{5}$ 678.3096, found 678.3110. Anal. Calcd for $\mathrm{C}_{44} \mathrm{H}_{42} \mathrm{~N}_{2} \mathrm{O}_{5}$ : C , 77.84; H, 6.24; N, 4.13. Found: C, 77.76; H, 6.40; N, 4.22.

Data for 5,11,17-Triallyl-23-(p-nitrophenyl)azo$\mathbf{2 5 , 2 6 , 2 7 , 2 8 - t e t r a h y d r o x y c a l i x}[4]$-arene, $4 c$. The solid was eluted with hexane/chloroform $(\mathrm{v} / \mathrm{v}=2 / 1)$ and gave $0.47 \mathrm{~g}$ $(73 \%)$ of a deep red powder, $\mathrm{mp} 256-259{ }^{\circ} \mathrm{C}$ (dec): ${ }^{1} \mathrm{H}$ NMR $\left(300 \mathrm{MHz}, \mathrm{CDCl}_{3}\right) \delta 10.22(\mathrm{~s}, 4 \mathrm{H}, \mathrm{OH}), 8.37-8.33(\mathrm{~m}, 2 \mathrm{H})$, $7.95-7.92(\mathrm{~m}, 2 \mathrm{H}), 7.73(\mathrm{~s}, 2 \mathrm{H}), 6.95-6.85(\mathrm{~m}, 6 \mathrm{H}), 5.92-5.80$ $(\mathrm{m}, 3 \mathrm{H}), 5.08-5.00(\mathrm{~m}, 6 \mathrm{H}), 4.40-4.20(\mathrm{bs}, 4 \mathrm{H}), 3.70-3.40$ (bd, $4 \mathrm{H}), 3.22-3.16(\mathrm{~m}, 6 \mathrm{H}) ;{ }^{13} \mathrm{C} \mathrm{NMR}\left(\mathrm{CDCl}_{3}\right) \delta 156.0\left(\mathrm{C}_{\mathrm{q}}\right), 153.4$ $\left(\mathrm{C}_{\mathrm{q}}\right), 148.2\left(\mathrm{C}_{\mathrm{q}}\right), 147.3\left(\mathrm{C}_{\mathrm{q}}\right), 146.9\left(\mathrm{C}_{\mathrm{q}}\right), 146.8\left(\mathrm{C}_{\mathrm{q}}\right), 137.4(\mathrm{CH})$, $133.9\left(\mathrm{C}_{\mathrm{q}}\right), 133.7\left(\mathrm{C}_{\mathrm{q}}\right), 129.3(\mathrm{CH}), 129.3(\mathrm{CH}), 129.1(\mathrm{CH}), 129.0$ $(\mathrm{CH}), 128.4\left(\mathrm{C}_{\mathrm{q}}\right), 127.9\left(\mathrm{C}_{\mathrm{q}}\right), 127.2\left(\mathrm{C}_{\mathrm{q}}\right), 124.7(\mathrm{CH}), 123.1(\mathrm{CH})$, $115.7\left(\mathrm{CH}_{2}\right), 115.6\left(\mathrm{CH}_{2}\right), 39.3\left(\mathrm{CH}_{2}\right), 31.8\left(\mathrm{CH}_{2}\right), 31.7\left(\mathrm{CH}_{2}\right)$; FAB-MS $m / z 694\left(\mathrm{M}+\mathrm{H}^{+}\right)$; HRMS $m / z$ calcd for $\mathrm{C}_{43} \mathrm{H}_{39} \mathrm{~N}_{3} \mathrm{O}_{6}$ 693.2841, found 693.2823. Anal. Calcd for $\mathrm{C}_{43} \mathrm{H}_{39} \mathrm{~N}_{3} \mathrm{O}_{6}$ : C, 74.43; H, 5.67; N, 6.06. Found: C, 74.04; H, 5.68; N, 6.25.

General Procedure for the Synthesis of 5,17-Bis-(3hydroxypropyl)-11,23 bisarylazocalix [4] arenes 5a,b. ${ }^{6}$ To a solution of $\mathbf{3 a}(60 \mathrm{mg}, 0.080 \mathrm{mmol})$ in tetrahydrofuran $(7$ $\mathrm{mL}$ ) was added $\mathrm{BH}_{3} \cdot \mathrm{THF}(0.30-0.33 \mathrm{~mL}$ of $1 \mathrm{M}$ solution) dropwise over a period of $20 \mathrm{~min}$. The solution was stirred for $1 \mathrm{~h}$ at room temperature, and then water $(2 \mathrm{~mL})$ was added slowly to destroy excess $\mathrm{BH}_{3}$. The $\mathrm{pH}$ was raised by addition of $3 \mathrm{~mL}$ of sodium hydroxide ( $3 \mathrm{M}$ aqueous solution), and then $\mathrm{H}_{2} \mathrm{O}_{2}$ (3 mL of a $30 \%$ solution) was added dropwise over 10 min. The solution was hated to $30-50{ }^{\circ} \mathrm{C}$ for $15 \mathrm{~min}$ and then stirred at room temperature for $1 \mathrm{~h}$. The solution was then extracted with ethyl acetate $(3 \times 30 \mathrm{~mL})$, and the combined extracts were washed with water $(2 \times 30 \mathrm{~mL})$ and brine $(50$ $\mathrm{mL}$ ) and then dried over magnesium sulfate. The solution was removed, and the residue was purified by column chromatography with hexane and ethyl acetate as an eluent and gave the corresponding 3-hydroxypropyl-arylazocalix[4]arenes 5a and $\mathbf{5 b}$ in 39 and $58 \%$ yields, respectively.

Data for 5,17-Bis(3-hydroxypropyl)-11,23-bis(phenyl)azocalix[4]arenes 5a. The solid was eluted with hexane/ethyl acetate $(\mathrm{v} / \mathrm{v}=1 / 1)$ and gave $24 \mathrm{mg}(39 \%)$ of an orange powder, $\mathrm{mp} 263-267{ }^{\circ} \mathrm{C}(\mathrm{dec}):{ }^{1} \mathrm{H} \mathrm{NMR}\left(300 \mathrm{MHz}, \mathrm{CDCl}_{3}\right) \delta 10.22(\mathrm{bs}$, $4 \mathrm{H}, \mathrm{OH}), 7.82-7.79(\mathrm{~m}, 4 \mathrm{H}), 7.68(\mathrm{~s}, 4 \mathrm{H}), 7.50-7.41(\mathrm{~m}, 6 \mathrm{H})$, $7.05-7.01(\mathrm{~m}, 4 \mathrm{H}), 4.40-4.28(\mathrm{bd}, 4 \mathrm{H}), 3.72-3.55(\mathrm{~m}, 8 \mathrm{H})$, $2.57-2.51(\mathrm{~m}, 4 \mathrm{H}), 1.86-1.76(\mathrm{~m}, 4 \mathrm{H}) ;{ }^{13} \mathrm{C} \mathrm{NMR}\left(\mathrm{CDCl}_{3}\right) \delta$ $152.7\left(\mathrm{C}_{\mathrm{q}}\right), 151.8\left(\mathrm{C}_{\mathrm{q}}\right), 147.5\left(\mathrm{C}_{\mathrm{q}}\right), 146.6\left(\mathrm{C}_{\mathrm{q}}\right), 135.9\left(\mathrm{C}_{\mathrm{q}}\right), 130.4$ $(\mathrm{CH}), 129.3(\mathrm{CH}), 129.0(\mathrm{CH}), 128.8\left(\mathrm{C}_{\mathrm{q}}\right), 127.6(\mathrm{CH}), 124.0$ $(\mathrm{CH}), 122.5(\mathrm{CH}), 62.0\left(\mathrm{CH}_{2}\right), 34.0\left(\mathrm{CH}_{2}\right), 31.8\left(\mathrm{CH}_{2}\right), 31.0$ $\left(\mathrm{CH}_{2}\right)$; FAB-MS $\mathrm{m} / \mathrm{z} 750\left(\mathrm{M}+\mathrm{H}^{+}\right)$; HRMS m/z calcd for $\mathrm{C}_{46} \mathrm{H}_{44} \mathrm{~N}_{4} \mathrm{O}_{6} 748.3263$, found 748.3242 .

Data for 5,17-Bis(3-hydroxypropyl)-11,23-bis(pmethoxyphenyl)azocalix[4]arenes $5 \mathbf{b}$. The solid was eluted with hexane/ethyl acetate $(\mathrm{v} / \mathrm{v}=1 / 1)$ and gave $36 \mathrm{mg}(58 \%)$ of 
a yellow powder, $\mathrm{mp} 267-271{ }^{\circ} \mathrm{C}(\mathrm{dec}):{ }^{1} \mathrm{H} \mathrm{NMR}(300 \mathrm{MHz}$, $\left.\mathrm{CDCl}_{3}\right) \delta 10.20(\mathrm{bs}, 4 \mathrm{H}, \mathrm{OH}), 7.83-7.79(\mathrm{~m}, 4 \mathrm{H}), 7.63(\mathrm{~s}, 4 \mathrm{H})$, $7.02-6.94(\mathrm{~m}, 8 \mathrm{H}), 4.37-4.23(\mathrm{bd}, 4 \mathrm{H}), 3.86(\mathrm{~s}, 6 \mathrm{H}), 3.70-3.53$ $(\mathrm{m}, 8 \mathrm{H}), 2.56-2.50(\mathrm{~m}, 4 \mathrm{H}), 1.83-1.75(\mathrm{~m}, 4 \mathrm{H}) ;{ }^{13} \mathrm{C} \mathrm{NMR}$ $\left(\mathrm{CDCl}_{3}\right) \delta 161.6\left(\mathrm{C}_{\mathrm{q}}\right), 151.2\left(\mathrm{C}_{\mathrm{q}}\right), 147.5\left(\mathrm{C}_{\mathrm{q}}\right), 147.0\left(\mathrm{C}_{\mathrm{q}}\right), 146.6$ $\left(\mathrm{C}_{\mathrm{q}}\right), 135.8\left(\mathrm{C}_{\mathrm{q}}\right), 129.3(\mathrm{CH}), 128.8\left(\mathrm{C}_{\mathrm{q}}\right), 128.0\left(\mathrm{C}_{\mathrm{q}}\right), 124.3(\mathrm{CH})$, $123.6(\mathrm{CH}), 114.1(\mathrm{CH}), 62.0\left(\mathrm{CH}_{2}\right), 55.5\left(\mathrm{CH}_{3}\right), 34.0\left(\mathrm{CH}_{2}\right), 31.8$ $\left(\mathrm{CH}_{2}\right), 31.0\left(\mathrm{CH}_{2}\right) ; \mathrm{FAB}-\mathrm{MS} \mathrm{m} / \mathrm{z} 809\left(\mathrm{M}+\mathrm{H}^{+}\right)$; HRMS $\mathrm{m} / \mathrm{z}$ calcd for $\mathrm{C}_{48} \mathrm{H}_{48} \mathrm{~N}_{4} \mathrm{O}_{8}$ 808.3474, found 808.3369.

General Procedures for the Lower Rim Esterification of the Azo 3b and 3c to Give Compounds $6 b$ and 6c. The method is adapted from a procedure reported by Chang ${ }^{7 \mathrm{c}}$ et al. for lower rim esterification of calix[4] arene. Compound $\mathbf{3 b}$ or 3c (30 mg, 0.037-0.042 mmol) was dissolved in dry THF $(4 \mathrm{~mL})$, and then ethyl bromoacetate $(0.1 \mathrm{~mL}, 0.75-0.84 \mathrm{mmol}$, 20 equiv) and $\mathrm{NaH}(20 \mathrm{mg}, 0.75-0.84 \mathrm{mmol}, 20$ equiv) were added under nitrogen. The resulting mixture was stirred at $50{ }^{\circ} \mathrm{C}$ for $9 \mathrm{~h}$. After the mixture was cooled to room temperature, the solvent was removed under reduced pressure, and the residue was redissolved in chloroform and washed with water. The chloroform solution was dried over $\mathrm{MgSO}_{4}$ and evaporated to give the solid crude product. Column chromatography on silica gel eluting with hexane/ethyl acetate (v/v $=4 / 1$ ) gave the desired tetraesters $\mathbf{6 b}$ and $\mathbf{6 c}$ in 74 and $36 \%$ yields, respectively.

Data for 5,17-Diallyl-11,23-bis(p-methoxyphenyl)azo$\mathbf{2 5 , 2 6 , 2 7 , 2 8 - t e t r a k i s ( ( e t h o x y c a r b o n y l ) m e t h o x y ) c a l i x [ 4 ] - ~}$ arene 6b. A yellow solid of $32 \mathrm{mg}(74 \%)$ was obtained, $\mathrm{mp}$ $150-152{ }^{\circ} \mathrm{C}:{ }^{1} \mathrm{H} \mathrm{NMR}\left(300 \mathrm{MHz}, \mathrm{CDCl}_{3}\right) \delta 7.78-7.74(\mathrm{~m}, 4 \mathrm{H})$, $7.44(\mathrm{~s}, 4 \mathrm{H}), 6.93-6.88(\mathrm{~m}, 4 \mathrm{H}), 6.45(\mathrm{~s}, 4 \mathrm{H}), 5.79-5.64(\mathrm{~m}$, $2 \mathrm{H}), 4.94-4.81(\mathrm{~m}, 12 \mathrm{H}), 4.66(\mathrm{~s}, 4 \mathrm{H}), 4.29-4.17(\mathrm{~m}, 8 \mathrm{H})$, $3.90-3.87(\mathrm{~m}, 6 \mathrm{H}), 3.35(\mathrm{~d}, 4 \mathrm{H}, J=13.6 \mathrm{~Hz}), 2.97(\mathrm{~d}, 4 \mathrm{H}, J=$ $6.4 \mathrm{~Hz}), 1.35-1.27(\mathrm{~m}, 12 \mathrm{H}) ;{ }^{13} \mathrm{C}$ NMR $\left(75.4 \mathrm{MHz} \mathrm{CDCl}_{3}\right) \delta$ $170.1\left(\mathrm{C}_{\mathrm{q}}\right), 169.9\left(\mathrm{C}_{\mathrm{q}}\right), 161.5\left(\mathrm{C}_{\mathrm{q}}\right), 158.6\left(\mathrm{C}_{\mathrm{q}}\right), 153.7\left(\mathrm{C}_{\mathrm{q}}\right), 148.2$ $\left(\mathrm{C}_{\mathrm{q}}\right), 147.0\left(\mathrm{C}_{\mathrm{q}}\right), 137.8(\mathrm{CH}), 135.9\left(\mathrm{C}_{\mathrm{q}}\right), 134.5\left(\mathrm{C}_{\mathrm{q}}\right), 133.2\left(\mathrm{C}_{\mathrm{q}}\right)$, $128.7(\mathrm{CH}), 124.3(\mathrm{CH}), 123.2(\mathrm{CH}), 115.1\left(\mathrm{CH}_{2}\right), 114.0(\mathrm{CH})$, $71.6\left(\mathrm{CH}_{2}\right), 71.2\left(\mathrm{CH}_{2}\right), 60.6\left(\mathrm{CH}_{2}\right), 60.5\left(\mathrm{CH}_{2}\right), 55.4\left(\mathrm{CH}_{3}\right), 39.3$ $\left(\mathrm{CH}_{2}\right), 31.5\left(\mathrm{CH}_{2}\right), 14.2\left(\mathrm{CH}_{3}\right), 14.2\left(\mathrm{CH}_{3}\right) ; \mathrm{FAB}-\mathrm{MS} \mathrm{m} / \mathrm{z} 1118$ $\left(\mathrm{M}+2 \mathrm{H}^{+}\right), 1140\left(\mathrm{M}+\mathrm{H}^{+}+\mathrm{Na}^{+}\right) ; \operatorname{HRMS}\left(\mathrm{M}+\mathrm{H}^{+}\right) \mathrm{m} / z$ calcd for $\mathrm{C}_{64} \mathrm{H}_{69} \mathrm{~N}_{4} \mathrm{O}_{14}$ 1117.4813, found 1117.4801.

Data for 5,17-Diallyl-11,23-bis(p-nitrophenyl)azo-25, 26,27,28-tetrakis((ethoxycarbonyl)methoxy)calix[4]arene 6c. A red solid of $15 \mathrm{mg}(36 \%)$ was obtained, $\mathrm{mp} 180$ $183^{\circ} \mathrm{C}:{ }^{1} \mathrm{H} \mathrm{NMR}\left(300 \mathrm{MHz}, \mathrm{CDCl}_{3}\right) \delta 8.17-8.13(\mathrm{~m}, 4 \mathrm{H}), 7.76-$ $7.71(\mathrm{~m}, 4 \mathrm{H}), 7.35(\mathrm{~s}, 4 \mathrm{H}), 6.60(\mathrm{~s}, 4 \mathrm{H}), 5.86-5.77(\mathrm{~m}, 2 \mathrm{H})$, $4.97-4.85(\mathrm{~m}, 12 \mathrm{H}), 4.73(\mathrm{~s}, 4 \mathrm{H}), 4.28-4.18(\mathrm{~m}, 8 \mathrm{H}), 3.36(\mathrm{~d}$, $4 \mathrm{H}, J=13.7 \mathrm{~Hz}), 3.09(\mathrm{~d}, 4 \mathrm{H}, J=6.2 \mathrm{~Hz}), 1.34-1.23(\mathrm{~m}, 12 \mathrm{H})$;

${ }^{13} \mathrm{C} \mathrm{NMR}\left(\mathrm{CDCl}_{3}\right) \delta 170.0\left(\mathrm{C}_{\mathrm{q}}\right), 169.7\left(\mathrm{C}_{\mathrm{q}}\right), 159.9\left(\mathrm{C}_{\mathrm{q}}\right), 155.6$
$\left(\mathrm{C}_{\mathrm{q}}\right), 154.1\left(\mathrm{C}_{\mathrm{q}}\right), 148.1\left(\mathrm{C}_{\mathrm{q}}\right), 148.0\left(\mathrm{C}_{\mathrm{q}}\right), 137.8(\mathrm{CH}), 135.9\left(\mathrm{C}_{\mathrm{q}}\right)$, $134.6\left(\mathrm{C}_{\mathrm{q}}\right), 133.7\left(\mathrm{C}_{\mathrm{q}}\right), 129.1(\mathrm{CH}), 124.4(\mathrm{CH}), 124.0(\mathrm{CH}), 122.9$ $(\mathrm{CH}), 115.2\left(\mathrm{CH}_{2}\right), 71.5\left(\mathrm{CH}_{2}\right), 71.3\left(\mathrm{CH}_{2}\right), 39.2\left(\mathrm{CH}_{2}\right), 31.6$ $\left(\mathrm{CH}_{2}\right), 14.2\left(\mathrm{CH}_{3}\right), 14.6\left(\mathrm{CH}_{3}\right)$; FAB-MS $\mathrm{m} / \mathrm{z} 1148\left(\mathrm{M}+2 \mathrm{H}^{+}\right)$, $1170\left(\mathrm{M}+\mathrm{H}+\mathrm{Na}^{+}\right)$; HRMS $\mathrm{m} / z$ calcd for $\mathrm{C}_{62} \mathrm{H}_{62} \mathrm{~N}_{6} \mathrm{O}_{16}$ 1146.4225, found 1146.4252 .

General Procedures for UV/vis Experiments. Because of the poor solubility of metal perchlorates in chloroform, all of the UV/vis experiments reported in this work were carried out in a methanol-chloroform $(\mathrm{v} / \mathrm{v}=1 / 399)$ cosolvent unless otherwise specified. UV/vis spectra were recorded on an HP8453 spectrophotometer with a diode array detector, and the resolution was set at $1 \mathrm{~nm}$. The complexes were mixed and kept stirring for at least 20 min before measurements. During the measurements, the temperature of the quartz sample cell and the chamber was kept at $25{ }^{\circ} \mathrm{C}$.

Stability Constants of Metal Complexes. The stability constants $K_{\mathrm{a}}$ of a $1: 1$ complex of $\mathbf{3 a}-\mathbf{c}, \mathbf{4 a}-\mathbf{c}$, and $\mathbf{5 a}, \mathbf{b}$ with four transition metal ions $\left(\mathrm{Cr}^{3+}, \mathrm{Ni}^{2+}, \mathrm{Cu}^{2+}\right.$, and $\left.\mathrm{Hg}^{2+}\right)$ were determined from the following Benesi-Hilderbrand equation: ${ }^{12}$

$$
1 / \Delta A=1 / \Delta A_{\text {sat }}+1 /\left(\Delta A_{\text {sat }} K_{\mathrm{a}} \text { [guest] }\right)
$$

where $\Delta A$ is the absorption difference between the apparent metal complex and the free ionophores and $\Delta A_{\text {sat }}$ is the absorption difference at saturation. The association constant values $K_{\mathrm{a}}$ were evaluated graphically by plotting $1 / \Delta A$ against $1 /[$ metal ion]. In this study, the concentration of the ionophores was kept constant $(10 \mu \mathrm{M}$ for $\mathbf{3 a}-\mathbf{c}$ and $\mathbf{5 a}, \mathbf{b}$ and $20 \mu \mathrm{M}$ for $4 \mathbf{a}-\mathbf{c})$, and the concentration of metal ions was kept in the range [metal ion]/[ionophores] $=0.1-2.0$. All plots gave a straight line, and the $K_{\text {a values were obtained from the slopes }}$ and intercepts of this line (See Supporting Information).

Acknowledgment. We thank the National Science Council of the Republic of China for financial support (Grants NSC 90-2113-M-009-017 and 91-2113-M-009011).

Supporting Information Available: IR spectra, UV/vis titration spectra, Job's plots, and Benesi-Hilderbrand plots of $\mathbf{3 b}$ and $\mathbf{6 b}$ with various transition metal ions and $\mathbf{6 c}$ with $\mathrm{Li}^{+}$and $\mathrm{Na}^{+}$ions; partial X-ray crystallography data for compounds $3 \mathbf{a}$ and $\mathbf{3 c} ;{ }^{1} \mathrm{H}$ NMR spectra of compounds $\mathbf{3 a}-\mathbf{c}$, $\mathbf{5 a}, \mathbf{b}$, and $\mathbf{6 b}, \mathbf{c}$. This material is available free of charge via the Internet at http://pubs.acs.org.

JO047880A 